\title{
Kontribusi Sektor Pertanian berdasarkan Keunggulan Wilayah di Kabupaten Bangka
}

\author{
Tirani*, Yudi Sapta Pranoto, Haryono Moelyo \\ Jurusan Agribisnis, Fakultas Pertanian Perikanan dan Biologi, Universitas Bangka Belitung. \\ *Corresponding author: tirani1126@gmail.com
}

\begin{abstract}
This study aims to describe the contribution of agriculture sector based on superior sub-sector (base) in Bangka Regency. This research was conducted in November 2016 until May 2017 in Bangka Regency. This research uses survey method. The research uses secondary data which collected from several agencies in Bangka District. The method of analysis is Location Quotient (LQ). The result of research shows that Bakam District has one base sub-sector that is annual estate sub-sector; Belinyu District has two basic sub-sectors, namely livestock sub-sector and fishery sub-sector; Merawang District has three sub sectors namely horticultural crops sub-sector, fishery sub-sector, and livestock sub-sector; West Mendo District has two basic sub-sectors, namely food crops sub-sector and annual crop sub-sector and other horticulture sub-sector; Pemali District has two sub-sectors, namely food crops and annual plantation sub-sector; Puding Besar District has one sub-sector that is the annual plantation sub-sector; Riau Silip District has two sub-sectors of base, namely food crop sub-sector and plantation sub-sector yearly; and Sungailiat District has three sub sectors namely horticulture and annual crops sub sector, fishery sub-sector, and livestock sub-sector.
\end{abstract}

Keywords: Agriculture sector; Contribution; Subsector base

Cite this as: Tirani, Pranoto, Y.S., \& Moelyo, H. 2018. Kontribusi Sektor Pertanian berdasarkan Keunggulan Wilayah di Kabupaten Bangka. Caraka Tani: Journal of Sustainable Agriculture. 33(1), 42-49. doi:http://dx.doi.org/10.20961/carakatani.v33i1.19662

\section{PENDAHULUAN}

Pembangunan pertanian merupakan suatu proses perubahan sosial. Implementasinya tidak hanya ditujukan untuk meningkatkan status dan kesejahteraan petani semata, tetapi sekaligus juga dimaksudkan untuk mengembangkan potensi sumberdaya manusia baik secara ekonomi, sosial, politik, budaya, lingkungan, maupun melalui perbaikan (improvement), pertumbuhan (growth) dan perubahan (change) (Iqbal dan Sudaryanto, 2008).

Pembangunan pertanian bukan hanya suatu proses atau kegiatan dalam menambah produksi pertanian, melainkan proses yang menghasilkan perubahan sosial baik nilai, norma, perilaku, taraf hidup masyarakat dan sebagainya. Demi mencapai pertumbuhan ekonomi yang baik dan meningkatkan kesejahteraan masyarakat yang lebih baik, khususnya pada petani.

Membahas permasalahan pembangunan perekonomian Indonesia, tidak lepas dari bagaimana meningkatkan sektor-sektor yang menjadi bagian dari perekonomian itu sendiri, terutama perekonomian di daerah-daerah Indonesia. Perencanaan pembangunan ekonomi daerah bisa dianggap sebagai perencanaan untuk memperbaiki kapasitas sektor-sektor dalam menciptakan nilai-nilai sumberdaya secara bertanggung jawab (Kuncoro, 2004).

Salah satu peluang dalam mengatasi permasalahan pembangunan ekonomi adalah perlunya penajaman orientasi pembangunan yang berbasis pada potensi daerah. Masing-masing daerah didorong tidak saja untuk lebih mampu mengambil peran dan prakarsa dalam perencanaan pembangunan, tetapi juga untuk lebih jeli mengeksplorasi dan mengeksploitasi sumber daya yang bertujuan untuk mensejahterakan rakyat setempat (Prawoto, 2010).

Provinsi Kepulauan Bangka Belitung yang terkenal sebagai daerah penghasil timah terbesar di Indonesia. Daerah yang memiliki kandungan bijih timah ini banyak dijumpai di sebagian besar wilayahnya baik di perairan maupun di daratan, 
termasuk wilayah Kabupaten Bangka (Irnawati, 2015).

Keberadaan timah di daerah yang terkenal dengan semboyan "Sepintu Sedulang" ini, tentu telah memberikan kontribusi terhadap perekonomian daerah. Meskipun sektor pertambangan merupakan salah satu sektor unggulan yang menjadi sumber perekonomian
Kabupaten Bangka, namun dalam beberapa tahun terakhir ini sektor pertanian juga telah memberikan kontribusinya terhadap perekonomian Kabupaten Bangka. Kontribusi sektor pertanian dapat dilihat pada Tabel 1, nilai dan kontribusi sektor dalam Produk Domestik Regional Bruto (PDRB) atas dasar harga konstan Kabupaten Bangka tahun 2013-2015 berikut ini.

Tabel 1. Nilai dan Kontribusi Sektor dalam PDRB Atas Dasar Harga Konstan Kabupaten Bangka Tahun 2013-2015

\begin{tabular}{|c|c|c|c|c|c|c|}
\hline \multirow{2}{*}{ No. } & \multirow{2}{*}{ Sektor } & \multicolumn{3}{|c|}{ Nilai (juta rupiah) } & \multirow{2}{*}{$\begin{array}{c}\text { Rataan } \\
\text { (juta rupiah) }\end{array}$} & \multirow{2}{*}{$\begin{array}{l}\text { Persentase } \\
(\%)\end{array}$} \\
\hline & & 2013 & $2014 *$ & $2015^{* *}$ & & \\
\hline 1. & $\begin{array}{l}\text { Pertanian, Kehutanan, dan } \\
\text { Perikanan }\end{array}$ & 1.446 .154 & 1.589.084 & 1.695 .425 & $1.576 .887,67$ & 19,37 \\
\hline 2. & $\begin{array}{l}\text { Pertambangan dan } \\
\text { Penggalian }\end{array}$ & 1.261 .583 & 1.281 .590 & 1.307.078 & $1.283 .417,00$ & 15,76 \\
\hline 3. & Industri Pengolahan & 1.956.247 & 1.992.163 & 2.069 .455 & $2.005 .955,00$ & 24,64 \\
\hline 4. & $\begin{array}{l}\text { Pengadaan Listrik dan } \\
\text { Gas }\end{array}$ & 12.869 & 13.567 & 14.317 & $13.584,33$ & 0,17 \\
\hline 5. & $\begin{array}{l}\text { Pengadaan Air, } \\
\text { Pengelolaan Sampah, } \\
\text { Limbah, dan Daur Ulang }\end{array}$ & 1.449 & 1.525 & 1.607 & $1.527,00$ & 0,02 \\
\hline 6. & $\begin{array}{l}\text { Konstruksi } \\
\text { Pedagang Besar dan }\end{array}$ & 620.616 & 646.899 & 681.427 & $649.647,33$ & 7,98 \\
\hline 7. & $\begin{array}{l}\text { Eceran; Reparasi Mobil } \\
\text { dan Sepeda Motor }\end{array}$ & 923.756 & 967.061 & 1.007 .768 & $966.195,00$ & 11,87 \\
\hline 8. & $\begin{array}{l}\text { Transportasi dan } \\
\text { Pergudangan }\end{array}$ & 151.730 & 163.506 & 172.607 & $162.614,33$ & 2,00 \\
\hline 9. & $\begin{array}{l}\text { Penyediaan Akomodasi } \\
\text { dan Makan Minum }\end{array}$ & 169.984 & 183.073 & 189.902 & $180.986,33$ & 2,22 \\
\hline 10. & $\begin{array}{l}\text { Informasi dan } \\
\text { Komunikasi }\end{array}$ & 156.739 & 166.529 & 178.508 & $167.258,67$ & 2,05 \\
\hline 11. & $\begin{array}{l}\text { Jasa Keuangan dan } \\
\text { Asuransi }\end{array}$ & 212.743 & 216.761 & 223.203 & $217.569,00$ & 2,67 \\
\hline 12. & Real Estate & 260.005 & 281.126 & 285.552 & $275.561,00$ & 3,38 \\
\hline 13. & $\begin{array}{l}\text { Jasa Perusahaan } \\
\text { Administrasi }\end{array}$ & 16.716 & 17.949 & 18.670 & $17.778,33$ & 0,22 \\
\hline 14. & $\begin{array}{l}\text { Pemerintahan, Pertahanan } \\
\text { dan Jaminan Sosial Wajib }\end{array}$ & 337.844 & 363.903 & 389.959 & $363.902,00$ & 4,47 \\
\hline 15. & Jasa Pendidikan & 127.542 & 137.178 & 147.755 & $137.491,67$ & 1,69 \\
\hline 16. & $\begin{array}{l}\text { Jasa Kesehatan dan } \\
\text { Kegiatan Sosial }\end{array}$ & 70.493 & 74.930 & 78.848 & $74.757,00$ & 0,92 \\
\hline 17. & Jasa Lainnya & 42.646 & 46.212 & 49.909 & $46.255,67$ & 0,57 \\
\hline & Jumlah & & & & $8.141 .387,33$ & 100,00 \\
\hline
\end{tabular}

Sumber: PDRB Kabupaten Bangka, BPS (2016)

Catatan :

* Angka Sementara

** Angka Sangat Sementara

Berdasarkan Tabel 1, dapat dijelaskan bahwa jumlah rata-rata nilai sektor di Kabupaten Bangka tahun 2013 sampai dengan tahun 2015 atas harga konstan adalah sebesar Rp 8.141.387,33-. Sektor sektor pertanian memberikan kontribusi terbesar kedua setelah sektor industri pengolahan yaitu 
sebesar 19,37\% atau Rp 1.576.887,67-. Namun dari tahun 2013 sampai dengan tahun 2015, sektor pertanian memberikan kontribusi tertinggi yang dilihat dari laju pertumbuhannya dibandingkan dengan sektor industri pengolahan.

Pembangunan pada sektor pertanian di Kabupaten Bangka merupakan salah satu hal yang sangat penting dalam meningkatkan kehidupan sosial ekonomi masyarakat, karena sektor pertanian menjadi sektor unggulan dalam pembangunan di Kabupaten Bangka (Dispernak, 2013). Hal ini sesuai dengan Visi Kabupaten Bangka yaitu menuju "BANGKA BERMARTABAT".

Sektor pertanian mencakup tanaman bahan makanan, peternakan, perkebunan, hortikultura, perikanan, dan kehutanan. Sektor pertanian berperan besar dalam perekonomian masyarakat Kabupaten Bangka. Salah satu upaya yang perlu dilakukan untuk meningkatkan kesejahteraan masyarakat, yaitu dengan cara melakukan peningkatan kontribusi sektor pertanian berdasarkan keunggulan wilayah melalui penetapan subsektor unggulan.

Penetapan subsektor unggulan pada sektor pertanian harus disesuaikan berdasarkan potensi sumberdaya alam dan sumberdaya manusia yang dimiliki oleh daerah. Subsektor unggulan adalah subsektor yang memiliki produktivitas yang tinggi dan dapat memberikan nilai tambah sehingga berdampak positif bagi kesejahteraan masyarakat. Selain itu penetapan subsektor unggulan daerah juga harus mempertimbangkan kontribusi suatu komoditas pada setiap subsektor pertanian terhadap pertumbuhan ekonomi dan aspek pemerataan pembangunan pada suatu daerah (Syahroni, 2000).

Pengembangan sektor pertanian yang sesuai dan sangat menguntungkan secara ekonomi, sangat penting dalam perencanaan pengkajian teknologi untuk pengembangan subsektor unggulan dengan mempertimbangkan kemampuan sumberdaya lahan, sumberdaya manusia, dan kelembagaan sehingga pengembangan suatu komoditas unggulan dapat berkelanjutan (Hendayana, 2003).

Pembangunan pertanian yang ada sekarang ini untuk menjalankan visi dan misi pemerintah Kabupaten Bangka Tahun 2013-2018. Salah satu misi pemerintah daerah Kabupaten Bangka adalah "Mewujudkan Pertanian yang Tangguh" (RPJMD, 2013).

Sektor pertanian juga memiliki peranan yang terus berkembang dari tahun 2013 hingga 2015. Sektor pertanian memberikan kontribusi sebesar 21,44\% dari seluruh total PDRB Kabupaten Bangka tahun 2016. Laju pertumbuhan PDRB kategori pertanian, kehutanan dan perikanan (persen) tahun 2013 hingga 2015 dapat dilihat pada Tabel 2 berikut ini.

Tabel 2. Laju Pertumbuhan dan Peranan Terhadap PDRB Kategori Pertanian, Kehutanan dan Perikanan Tahun 2013 - 2015

\begin{tabular}{clcccc}
\hline No. & \multicolumn{1}{c}{ Subsektor } & $2013(\%)$ & $2014(\%)$ & $2015(\%)$ & Rata-rata $(\%)$ \\
\hline 1. & Tanaman Pangan & 9,30 & 0,36 & 3,74 & 4,47 \\
2. & Tanaman Hortikultura Semusim & 5,10 & 7,37 & 5,72 & 6,06 \\
3. & Tanaman Hortikultura Tahunan dan Lainnya & 5,43 & 10,01 & 7,90 & 7,78 \\
4. & Perkebunan Tahunan & 8,60 & 13,78 & 7,78 & 10,05 \\
5. & Peternakan & 5,95 & 6,88 & 5,77 & 6,20 \\
6. & Jasa Pertanian dan Perburuan & 7,16 & 7,46 & 8,43 & 7,68 \\
7. & Kehutanan dan Penebangan Kayu & 5,48 & 6,74 & 4,40 & 5,54 \\
8. & Perikanan & 6,94 & 6,51 & 5,50 & 6,32 \\
\hline
\end{tabular}

Sumber: PDRB Kabupaten Bangka, BPS (2016)

Berdasarkan Tabel 2, dapat diketahui laju pertumbuhan sektor pertanian terhadap PDRB terus berkembang dan meningkat. Sehingga hal ini dapat menjadi peluang yang besar apabila penetapan subsektor unggulan dapat dikembangkan secara luas dan komersial. Sehingga upaya mewujudkan pertanian tangguh diharapkan dapat meningkatkan pendapatan petani serta membantu program pemerintah dalam usaha meningkatkan pendapatan daerah. Berdasarkan uraian diatas, maka penelitian ini bertujuan untuk mendeskripsikan kontribusi sektor pertanian berdasarkan subsektor unggulan (basis) di Kabupaten Bangka. 


\section{METODE PENELITIAN}

Penelitian ini telah dilaksanakan di Kabupaten Bangka yang terbagi menjadi delapan kecamatan yang terdiri dari Kecamatan Sungailiat, Pemali, Merawang, Mendo Barat, Bakam, Puding Besar, Riau Silip dan Belinyu. Pemilihan lokasi penelitian dilakukan secara sengaja (Purposive Sampling) dengan mempertimbangkan bahwa Kabupaten Bangka sedang membangun kembali sektor pertanian yang sesuai dengan salah satu Misi Kabupaten Bangka tahun 2014-2018 yaitu "mewujudkan pertanian yang tangguh". Sedangkan waktu penelitian dilaksanakan pada bulan November 2016 hingga Mei 2017 di Kabupaten Bangka.

Penelitian ini menggunakan metode survei. Data yang digunakan merupakan data sekunder, melalui studi literatur bersumber dari beberapa publikasi jurnal, Instansi-instansi di Kabupaten Bangka seperti Dinas Pertanian, Badan Pusat Statistik, Badan Ketahanan Pangan, Dinas Kelautan dan Perikanan.

Metode pengolahan dan analisis data yaitu menggunakan analisis Location-Quotient (LQ). Untuk mengidentifikasi komoditas unggulan dapat menggunakan metode LQ yang diacu dari Miler dan Wright (1991), serta Ron Hood (1998). Mengacu kepada Hood (1998) Location Quotient merupakan suatu alat pengembangan ekonomi yang lebih sederhana dengan segala kelebihan dan keterbatasannya. Teknik LQ merupakan salah satu pendekatan yang umum digunakan dalam model ekonomi basis untuk memahami sektor kegiatan yang menjadi pemicu pertumbuhan. Mengacu pada Daryanto, (2010) LQ sebagai berikut:

$$
L Q_{i}=\frac{X_{1}^{R} / X^{* R}}{X_{1}^{N} / X^{* N}}
$$

Keterangan:

$$
\begin{aligned}
X_{1}^{R}= & \text { output sektor i di region } \mathrm{R} \\
X^{* R}= & \text { total output sektor-sektor yang } \\
& \text { menggunakan sektor i sebagai } \\
& \text { inputnya di region } \mathrm{R} \\
X_{1}^{N}= & \text { output sektor i secara nasional } \\
X^{* N}= & \text { total output sektor-sektor yang } \\
& \text { menggunakan sektor i sebagai } \\
& \text { inputnya secara nasional }
\end{aligned}
$$

Kemudian disederhakan lagi mengacu pada penelitian Septiana (2010). Rumus LQ untuk menentukan subsektor unggulan sebagai berikut:

$$
\mathrm{LQ}=\frac{\frac{\text { Jumlah Produksi Subsektor-i(Kecamatan-X) }}{\text { Jumlah Produksi Total Semua Subsektor(Kecamatan-X) }}}{\frac{\text { Jumlah Produksi Subsektor-i(Kabupaten-Y) }}{\text { Jumlah Produksi Total Semua Subsektor (Kabupaten-Y) }}}
$$

Keterangan:

$$
\begin{aligned}
\mathrm{LQ}>1= & \text { subsektor tersebut merupakan } \\
& \text { subsektor unggulan (basis). } \\
\mathrm{LQ}<1= & \text { berarti subsektor tersebut bukan } \\
& \text { subsektor unggulan (non basis). } \\
\mathrm{LQ}=1= & \begin{array}{l}
\text { produksi komoditas yang } \\
\text { bersangkut6an hanya cukup untuk } \\
\text { kebutuhan daerah setempat }
\end{array}
\end{aligned}
$$
$\mathrm{LQ}=1=$ produksi $\quad$ komoditas yang bersangkut6an hanya cukup untuk kebutuhan daerah setempat

\section{HASIL DAN PEMBAHASAN}

Mewujudkan pertanian yang tangguh merupakan salah satu misi Kabupaten Bangka tahun 2013 - 2018. Pertanian tangguh sebagai persyaratan bagi struktur ekonomi yang berimbang merupakan cara untuk mencapai peningkatan pendapatan dan kesejahteraan petani melalui peningkatan produksi pertanian yang terus menerus (Dispernak, 2013).

Berdasarkan Rencana Pembangunan Jangka Menengah Daerah (RPJMD) Kabupaten Bangka tahun 2013 - 2018, sektor pertanian di Kabupaten Bangka diharapkan menjadi sektor penggerak utama untuk masa yang akan datang (the nextprime mover), karena sektor ini mampu memberikan kontribusi besar dalam perekonomian, ditinjau dari aspek harga berlaku dan harga konstan.

Pada tahun 2015, sektor pertanian memberikan kontribusi sebesar $21,44 \%$ dari seluruh total PDRB Kabupaten Bangka (BPS, 2016). Subsektor perkebunan tahunan menjadi penyumbang terbesar yang membentuk PDRB sektor petanian. Subsektor perkebunan tahunan memberikan kontribusi yaitu sebesar 10,45\% dari total PDRB atau 48,7\% dari seluruh sektor petanian. Subsektor perikanan menjadi penyumbang terbesar kedua dengan kontribusi sebesar 5,78\% dari seluruh total PDRB tahun 2015 (BPS, 2016).

Menurut Budiharsono (2001) dalam teori basis ekonomi, perekonomian daerah dibagi menjadi dua sektor utama yaitu sektor basis dan sektor non basis. Sektor basis merupakan sektor yang mengekspor barang dan jasa ataupun tenaga kerja 
ke tempat di luar batas perekonomian daerahnya. Sektor non basis adalah sektor yang menyediakan barang dan jasa yang dibutuhkan oleh masyarakat yang bertempat tinggal di dalam batas-batas daerah itu sendiri.

Jika perekonomian mampu mengembangkan dan meningkatkan sektor basis, maka sektor basis akan mendorong sektor nonbasis sehingga pendapatan lokal akan meningkat melebihi peningkatan pendapatan lokal yang hanya mengandalkan sektor nonbasis. Dengan demikian, ekspor daerah merupakan penentu dalam pembangunan ekonomi daerah (Nurdianti, 2011).

Menurut Bendavid (1991) dalam Syarifudin (2003), Location Quotient (LQ) adalah suatu indeks untuk mengukur tingkat spesialisasi (relatif) suatu sektor atau subsektor ekonomi suatu wilayah tertentu. Pengertian relatif disini diartikan sebagai tingkat perbandingan suatu wilayah dengan wilayah yang lebih luas (wilayah referensinya), dimana wilayah yang diamati merupakan bagian dari wilayah yang lebih luas tersebut.

Menurut Septiana (2010), teknik LQ banyak digunakan untuk membahas kondisi perekonomian, mengarah pada identifikasi spesialisasi kegiatan perekonomian untuk mendapatkan gambaran dalam penetapan sektor suatu kegiatan ekonomi. Berdasarkan pemahaman terhadap teori ekonomi basis, teknik LQ relevan digunakan sebagai metode dalam menentukan komoditas unggulan khususnya dari sisi penawaran (produksi atau populasi).

Berdasarkan hasil penelitian Nurdianti (2011), indikator suatu sektor dikatakan sektor unggulan atau bukan sektor unggulan ialah ketika memiliki LQ yang lebih besar atau lebih kecil dari satu
(LQ>1 atau LQ<1). Apabila nilai LQ lebih besar dari satu maka sektor tersebut adalah sektor unggulan, artinya peranan suatu sektor dalam kabupaten lebih besar dari pada peranan sektor dalam provinsi. Hasil perhitungan nilai LQ untuk seluruh sektor perekonomian menunjukkan bahwa terdapat beberapa sektor ekonomi yang menjadi sektor basis.

Apabila sektor yang memiliki nilai LQ lebih dari satu (LQ>1), menunjukkan bahwa peranan sektor ekonomi cukup menonjol di daerah tersebut dan sektor tersebut mampu mengekspor sebagian dari nilai tambah yang dihasilkannya. Sebaliknya, apabila sektor yang memiliki nilai LQ kurang dari satu $(\mathrm{LQ}<1)$, maka sektor tersebut hanya mampu memenuhi pasar dalam negeri atau lokal daerah dan cenderung mengimpor dari wilayah lain (Basuki \& Gayatri, 2009).

Analisis LQ yang dilakukan dalam pembahasan penelitian ini diperlukan untuk menentukan subsektor unggulan yang ada di Kabupaten Bangka. Penentuan subsektor unggulan ini dilakukan agar Kabupaten Bangka khususnya Pemerintah Daerah dapat lebih memperhatikan pendapatan dan kesejahteraan masyarakat Kabupaten Bangka.

Subsektor unggulan atau subsektor yang berpotensi dalam perekonomian di Kabupaten Bangka dapat diketahui dan dapat dikembangkan, karena mampu melayani pasar di daerah itu sendiri maupun diluar daerah yang bersangkutan, yang tentunya akan mendapatkan surplus dari perkembangan sektor unggulan ini.

Adapun nilai Location Quotient (LQ) produksi subsektor pada sektor pertanian menurut kecamatan di Kabupaten Bangka tahun 2017, dapat dilihat pada Tabel 3 berikut ini.

Tabel 3. Nilai Location Quotient (LQ) Produksi Subsektor pada Sektor Pertanian Menurut Kecamatan di Kabupaten Bangka Tahun 2017

\begin{tabular}{clcccccc}
\hline No. & \multicolumn{1}{c}{ Kecamatan } & TP & THS & THT & PT & Pt & Pr \\
\hline 1. & Bakam & 0,85 & 0,14 & 0,07 & $\mathbf{1 , 4 4}$ & 0,03 & 0,00 \\
2. & Belinyu & 0,97 & 0,84 & 0,09 & 0,96 & $\mathbf{1 , 6 2}$ & $\mathbf{1 , 6 9}$ \\
3. & Mendo Barat & $\mathbf{1 , 3 8}$ & 0,76 & $\mathbf{2 , 0 5}$ & 0,85 & 0,09 & 0,97 \\
4. & Merawang & 0,82 & $\mathbf{3 , 5 3}$ & 0,52 & 0,96 & $\mathbf{1 , 8 5}$ & $\mathbf{1 , 0 3}$ \\
5. & Pemali & $\mathbf{1 , 1 0}$ & 0,59 & 0,06 & $\mathbf{1 , 3 7}$ & 0,36 & 0,04 \\
6. & Puding Besar & 0,91 & 0,54 & 0,32 & $\mathbf{1 , 2 7}$ & 0,11 & 0,45 \\
7. & Riau Silip & $\mathbf{1 , 5 2}$ & 0,87 & 0,25 & $\mathbf{1 , 1 1}$ & 0,39 & 0,81 \\
8. & Sungailiat & 0,45 & 0,82 & $\mathbf{4 , 4 8}$ & 0,01 & $\mathbf{4 , 2 0}$ & $\mathbf{3 , 1 1}$ \\
\hline
\end{tabular}

Sumber: Data Sekunder Sudah Diolah, 2017 


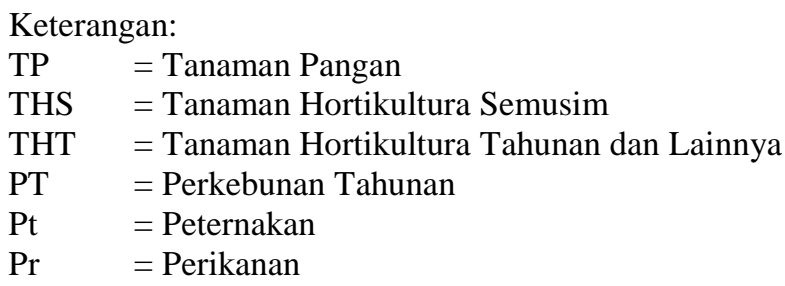

Berdasarkan Tabel 3, Kabupaten Bangka terdiri dari 8 kecamatan. Berdasarkan hasil analisis Location Quotient yaitu pada Tabel 3, terlihat bahwa subsektor basis yang paling banyak terdapat di kecamatan-kecamatan adalah subsektor perkebunan tahunan yaitu terdapat di 4 kecamatan. Sedangkan subsektor basis yang paling sedikit terdapat di kecamatan-kecamatan adalah subsektor tanaman hortikultura semusim, yaitu terdapat di satu kecamatan saja.

Berdasarkan Tabel 3, diketahui bahwa tiap kecamatan mempunyai subsektor basis yang berbeda-beda, dengan jumlah subsektor basis yang berbeda-beda pula. Perbedaan ini disebabkan oleh kinerja subsektor pertanian ditiap daerah yang antara lain dipengaruhi kekayaan alam, potensi sumberdaya manusia, bahkan kebijakan pemerintah kecamatan yang bersangkutan. Semakin besar nilai LQ maka semakin tinggi kinerja subsektor tersebut dibandingkan subsektor lain atau subsektor di daerah lain, sehingga nilai LQ menggambarkan keunggulan kompetitif suatu subsektor di suatu daerah (Wicaksono, 2011).

Kecamatan Merawang dan Kecamatan Sungailiat merupakan kecamatan yang memiliki subsektor basis terbanyak yaitu masing-masing sebanyak tiga subsektor.

a. Kecamatan Merawang memiliki tiga subsektor unggulan yaitu subsektor tanaman hortikultura semusim, subsektor peternakan, dan subsektor perikanan. Produksi subsektor perikanan tahun 2016 yaitu sebesar 3.586,68 ton, hal ini dikarenakan wilayahnya yang sangat dekat dengan pantai dan perairan payau (Dinas Kelautan dan Perikanan, 2016). Produksi subsektor peternakan di kecamatan ini sebesar 713,67 ton daging pada tahun 2016. Kecamatan Merawang terdapat peternak besar maupun peternak kecil, dan kecamatan ini terkenal dengan ayam merawangnya. Pada tahun 2016, produksi tanaman hortikultura semusim sebesar 2.130,50 ton (Dinas Pertanian, 2016). Tanaman hortikultura semusim menjadi subsektor basis, hal ini menunjukkan kebenaran bahwa Kecamatan Merawang memang dikenal masyarakat sebagai sentra sayuran, terutama di Desa Balunijuk.

b. Kecamatan Sungailiat memiliki tiga subsektor unggulan yaitu subsektor tanaman hortikultura tahunan dan lainnya, subsektor peternakan, dan subsektor perikanan. Pada tahun 2016 produksi masing-masing subsektor, yaitu subsektor tanaman hortikultura tahunan dan lainnya sebesar $8.086,10$ ton, subsektor peternakan sebesar 1.382,51 ton daging, dan subsektor perikanan sebesar 9.248,98 ton. Subsektor perikanan bisa menjadi subsektor basis karena wilayah kecamatan ini dikelilingi oleh banyak laut. Kecamatan Sungailiat memiliki populasi ternak dan unggas yang tinggi yaitu sebesar 94.010 ekor, sehingga subsektor peternakan bisa menjadi subsektor basis bagi kecamatan ini (Dinas Kelautan dan Perikanan, 2016). Sedangkan pada subsektor tanaman hortikultura tahunan yang menjadi subsektor basis, hal ini dikarenakan Sungailiat menjadi Ibukota Kabupaten Bangka dan menjadikan kecamatan ini menjadi pusat perdagangan (BPS, 2016).

Kecamatan yang memiliki subsektor basis terbanyak kedua yaitu Kecamatan Belinyu, Mendo Barat, Pemali, dan Riau Silip dengan jumlah subsektor masing-masing sebanyak dua subsektor.

a. Kecamatan Belinyu memiliki dua subsektor unggulan yaitu pada subsektor peternakan dan subsektor perikanan. Kecamatan Belinyu memiliki industri rumah tangga pengolahan hasil perikanan tertinggi yaitu sebesar 92 rumah tangga pengolahan. Produk-produk yang dipasarkan khas dari kecamatan ini antara lain adalah keretek, kempelang, kericu, otak-otak, dan lainnya (BPS, 2016). Dengan produksi subsektor perikanan sebesar 5.931,36 ton (Dinas Kelautan dan Perikanan). Kecamatan Belinyu memiliki jumlah populasi ternak dan unggas yang tinggi yaitu sebesar 65.566 ekor dan subsektor peternakan sebesar 
627,44 ton daging pada tahun 2016 (Dinas Pertanian, 2016).

b. Wilayah Kecamatan Mendo Barat sebagian besar terdiri dari lahan pertanian dan hutan. Hal ini membuat sektor pertanian menjadi sektor utama di kecamatan ini. Berdasarkan hasil perhitungan LQ, kecamatan ini memiliki dua subsektor unggulan yaitu subsektor tanaman pangan dan subsektor tanaman hortikultura tahunan dan lainnya. Pada tahun 2016 produksi subsektor tanaman pangan sebesar 3.069,31 ton dan subsektor tanaman hortikultura tahunan dan lainnya sebesar 5.767,90 ton (Dinas Pertanian, 2016). Kecamatan ini terkenal dengan subsektor perkebunan tahunan, terutama pada komoditi karet. Namun berdasarkan hasil perhitungan LQ, subsektor perkebunan tahunan bukan merupakan subsektor basis melainkan nonbasis.

c. Kecamatan Riau Silip memiliki dua subsektor unggulan yaitu subsektor tanaman pangan dan subsektor perkebunan tahunan. Pada tahun 2016, produksi subsektor tanaman pangan sebesar 2.092,23 ton dan subsektor perkebunan tahunan sebesar 13.882,96 ton (Dinas Pertanian, 2016). Pada subsektor tanaman pangan, jumlah produksi terbesar yaitu pada komoditas ketela pohon. Hal ini dikarenakan terdapat pabrik pengolahan ketela pohon, sehingga masyarakat banyak yang berusahatani ketela pohon. Selain itu, subsektor perkebunan pun menjadi subsektor unggulan di kecamatan ini. Hasil perkebunan di kecamatan ini berupa kelapa sawit, karet, lada, dan kelapa (BPS, 2016).

d. Kecamatan Pemali memiliki dua subsektor unggulan yaitu subsektor tanaman pangan dan subsektor perkebunan tahunan. Produksi masing-masing subsektor pada tahun 2016, yaitu 839,08 ton untuk subsektor tanaman pangan dan 9.488,35 ton untuk subsektor perkebunan tahunan (Dinas Pertanian, 2016). Walupun Kecamatan Pemali memiliki luas wilayah tersempit di Kabupaten Bangka yaitu hanya sebesar 2.725 hektar (BPS, 2016). Namun kecamatan ini mampu mengelola sektor pertanian dengan baik.

Sedangkan Kecamatan Bakam dan Puding Besar yang memiliki subsektor basis dengan jumlah terkecil yaitu pada subsektor perkebunan tahunan saja. a. Kecamatan Bakam hanya memiliki satu subsektor unggulan yaitu subsektor perkebunan tahunan. Dengan produksi tertinggi pada tahun 2016 yaitu sebesar 28.552,72 ton (Dinas Pertanian, 2016). Kecamatan ini berkembang dari subsektor perkebunan tahunan. Hal ini terlihat dari jumlah penduduk yang berprofesi sebagai petani sebesar 8.339 orang (BPS, 2016). Hasil perkebunan di kecamatan ini berupa kelapa sawit, karet, lada, dan kelapa.

b. Kecamatan Puding Besar memiliki satu subsektor unggulan yaitu subsektor perkebunan tahunan. Dengan produksi pada tahun 2016 yaitu sebesar 19.697,29 ton (Dinas Pertanian, 2016). Perkebunan tahunan masih menjadi primadona di kecamatan ini, terutama pada komoditas kelapa sawit. Dan terdapat tiga perusahaan perkebunan di Kecamatan Puding Besar.

Berdasarkan hasil perhitungan LQ, dapat diketahui setiap kecamatan di Kabupaten Bangka memiliki subsektor unggulan pada sektor pertanian. Dengan nilai LQ> 1 yang menunjukkan subsektor-subsektor tersebut merupakan subsektor basis yang memiliki peranan penting dalam perekonomian Kabupaten Bangka. Hal ini menunjukkan bahwa subsektor-subsektor basis tersebut mampu memenuhi kebutuhan di wilayah Kabupaten Bangka dan cenderung mampu untuk mengekspor ke wilayah lain.

Sedangkan nilai $L Q<1$, hal ini menunjukkan bahwa beberapa subsektor tersebut merupakan sektor non basis dan cenderung akan mengimpor dari wilayah lain (Basuki \& Gayatri, 2009). Hal ini perlu menjadi perhatian penting bagi pemerintah daerah Kabupaten Bangka dalam mengupayakan pengembangan subsektor unggulan bagi peningkatan perekonomian daerah di seluruh wilayah Kabupaten Bangka.

\section{KESIMPULAN}

Sektor Pertanian mampu memberikan kontribusi yang cukup besar bagi perekonomian daerah. Berdasarkan hasil analisis Location Quotient, terlihat bahwa subsektor basis yang paling banyak terdapat di kecamatan-kecamatan adalah subsektor perkebunan tahunan yaitu terdapat di 4 kecamatan, yaitu Kecamatan Bakam, Pemali, Puding Besar dan Riau Silip. Sedangkan subsektor basis yang paling sedikit terdapat di kecamatan-kecamatan adalah subsektor tanaman 
hortikultura semusim, yaitu hanya terdapat di Kecamatan Merawang.

\section{DAFTAR PUSTAKA}

Basuki, A.T., \& Gayatri, U. 2009. Penentu Sektor Unggulan dalam Pembangunan Daerah: Studi Kasus di Ogan Komering Ilir. Jurnal Ekonomi dan Studi Pembangunan.10(1), 34 - 50.

Badan Pusat Statistik [BPS]. 2016. Produk Domestik Regional Bruto (PDRB) Kabupaten Bangka.

Badan Pusat Statistik [BPS]. 2016. Kabupaten Bangka Dalam Angka.

Budiharsono, S. 2001. Teknik Pembangunan Wilayah Pesisir dan Lautan. Jakarta: PT Pradnya Paramita.

Daryanto, A \& Hafizrianda, Y. 2010. Analisis Input-Output \& Social Accounting Matrix untuk Pembangunan Ekonomi Daerah. Bogor: PT Penerbit IPB Press.

Dinas Pertanian. 2016. Produksi Sektor Pertanian Kabupaten Bangka Tahun 2016.

Dinas Kelautan dan Perikanan. 2016. Produksi Perikanan Kabupaten Bangka Tahun 2016.

Dispernak. 2013. Rencana Strategis (Renstra) Dinas Pertanian dan Peternakan Kabupaten Bangka Tahun 2013-2018.

Hendayana, R. 2003. Aplikasi Metode Location Quotient (LQ) dalam Penentuan Komoditas Unggulan Nasional. Jurnal Informatika Pertanian. 12, 1-21.

Iqbal, M., \& Sudaryanto. 2008. Tanggung Jawab Sosial Perusahaan (Corporate Social Responsibility) dalam Perspektif Kebijakan Pembangunan Pertanian. Jurnal Analisa Kebijakan Pertanian. 6(2), 155-173.

Irnawati. 2010. Kontribusi Sektor Perkebunan Terhadap Pendapatan Asli Daerah di
Kabupaten Bangka Tengah [Skripsi]. Bangka: UBB.

Kuncoro. 2004. Otonomi dan Pembangunan Daerah: Reformasi, Perencanaan, Strategi dan Peluang. Jakarta: Erlangga.

Miller, M.M., Gibson, J.L., \& Wright, G.N. 1991. Location Quotient Basic Tool for Economic Development Analysis. Economic Development Review. 9(2), 65

Nurdianti, I. 2011. Analisis Laju Pertumbuhan dan Daya Saing Sektor-sektor Perekonomian di Kabupaten Kerinci Periode 2005-2009 [Skripsi]. Bogor: Institut Pertanian Bogor.

Prawoto, N. 2010. Pengembangan Potensi Unggulan Sektor Pertanian. Jurnal Ekonomi dan Studi Pembangunan, 11(1), 1-19.

Hood, R. 1998. Economic Analysis: A Location Quotient, Primer. Principal Sun Region Associates, Inc.

RPJMD. 2013. Rencana Pembangunan Jangka Menengah Daerah (RPJMD) Kabupaten Bangka Tahun 2014-2018.

Septiana. 2010. Analisis Komoditas Unggulan Subsektor Tanaman Pangan di Kecamatan Koba Kabupaten Bangka Tengah [Skripsi]. Bangka: Universitas Bangka Belitung.

Syahroni. 2000. Analisis Strategi Pengembangan Komoditas Unggulan Agribisnis Kabupaten Dompu Provinsi Nusa Tenggara Barat [Skripsi]. Bogor: Institut Pertanian Bogor.

Syarifudin, L. 2003. Studi Pemilihan Subsektor Jasa Unggul dalam Rangka Mendukung Kota Bandung sebagai Kota Jasa. Informatek: Bandung.

Wicaksono, I.A. 2011. Analisis Location Quotient Sektor dan Subsektor Pertanian Pada Kecamatan di Kabupaten Purworejo. Mediagro. 7(2), 11-18. 